Dawsonia Nicholson: linguliform brachiopods, crustacean tail-pieces and a problematicum rather than graptolite ovarian vesicles

A reassessment of Dawsonia Nicholson

Alex Page, Philip R. Wilby, Claire Mellish, Mark Williams and Jan A. Zalasiewicz 
ABSTRACT: Though little is known of the graptoloid reproductive mechanism, graptolites with putatively sac-like appendages, supposedly ovarian vesicles, have been known from the Moffat Shales Group, Southern Uplands, Scotland, for over 150 years. Locally, these co-occur with isolated, two-dimensional, discoidal or ovatotriangular fossils. In the 1870 s, Nicholson interpreted these isolated fossils as being graptoloid 'egg-sacs', detached from their parent and existing as free-swimming bodies. He assigned them to the genus "Dawsonia", though the name was preoccupied by a trilobite, and named four species: "D. " campanulata, “D." acuminata, “D." rotunda (sic.) and “D." tenuistriata. A reassessment of Nicholson's type material from the Silurian of Moffatdale, Scotland, and the Ordovician Lévis Formation of Quebec, Canada, shows that Dawsonia Nicholson comprises the inarticulate brachiopods Acrosaccus? rotundus, Paterula? tenuistriata and Discotreta cf. levisensis, the tail-piece of the crustacean Caryocaris acuminata and the problematic fossil “D." campanulata. Though “D." campanulata resembles sac-like graptolite appendages, morphometric analysis reveals the similarity to be superficial and the systematic position of this taxon remains uncertain. There is no definite evidence of either “D." campanulata or sac-like graptoloid appendages having had a reproductive function.

KEYWORDS: Arenig, Llandovery, Canada, graptolites, Henry Nicholson, reproduction, Scotland, Silurian, taxonomy. 
Our knowledge of reproductive structures and strategies in the animal fossil record is sparse. Though reproductive organs are occasionally found, they usually require exceptional preservation for their true nature to be discerned (e.g. Siveter et al. 2003; Dunlop et al. 2004). Whilst a certain amount is known of the reproductive strategies and mechanisms of the pterobranch hemichordates (Gilchrist 1915; Stebbing 1970; Dilly 1973; Hutt 1991), the extant sister group of the graptolites (Kozłowski 1947, 1948; Towe \& Urbanek 1972; Crowther 1978; Cameron 2005), little is known about reproduction in the graptolites themselves (e.g. Urbanek \& Jaanusson 1974). Likewise, as little is known of the buoyancy mechanism employed by the graptoloids (Bates 1987), any putatively vesicular graptoloid tissues (e.g. Fig. 1d, f) tend to attract interest and debate (e.g. Underwood 1993; Rickards et al. 1994).

There are many gaps in our knowledge of the earliest developmental stages of the graptolites, especially surrounding the events prior to the dispersal of their prosiculae (cone-shaped larvae). Working on well-preserved material from the Tremadoc of Poland, Kozłowski (1948) showed clutches of eggs and embryos in the autothecae of benthonic graptolites; similar structures have also been found in Reticulograptus tuberosus, a bushy tuboid graptolite from Götland, Sweden (Bulman \& Rickards 1966). Unlike the graptoloids, benthonic graptolites have two types of thecae. These differentiated thecae have been interpreted as sexual dimorphs, with the smaller bithecae housing the male zooid and the larger autothecae housing the female (Kozłowski 1948), though this has yet to be confirmed. Nevertheless, the loss of bithecae in the graptoloids may indicate that their reproductive strategy altered as they colonised the plankton (Hutt 1991), and neither eggs nor embryos have been found in graptoloid thecae. Some workers have suggested that the graptolite synrhabdosome may represent short-lived congregations of several colonies in sexual congress (e.g. 
Zalasiewicz 1984) or asexually developing supercolonies (Ruedemann 1947; Bulman 1970). However, the nature of synrhabdosomes remains enigmatic (cf. Rigby 1993; Underwood 1993; Gutiérrez-Marco \& Lenz 1998).

In order to assess whether putatively vesicular graptoloid tissues played a role in reproduction, we have undertaken a thorough re-evaluation of sac-like graptolite appendages (Fig. 1d, f) and also of "Dawsonia” Nicholson 1873 (Figs 1, 2 \& 3), which was originally interpreted as being an ovarian vesicle of a graptoloid detached from its parent colony. Though this genus has a long history of research, it has “caused confusion ever since it was first described" (Williams, 1981). We initially establish the context in which the fossils were originally interpreted and how they have been subsequently reinterpreted, prior to re-evaluating them based on the original material and on new specimens.

\section{History of research}

Prior to Kozłowski's seminal monograph of 1948, the zoological affinities of the graptolites attracted much debate. They were initially thought to be a moss (Von Bromell 1727), to be artefacts (Linnaeus 1768), or even, as Nimmo (1847) suggested, the tail spines of the Indian Ocean ray Raja pastinaca, though Nimmo had probably never seen a graptolite (Elles \& Wood 1901-1918, p. xiii). Eventually, graptolites were recognised as colonies consisting of a series of cup-shaped orifices (thecae) and they were variously assigned to the Cnidaria and Bryozoa (see summaries in Elles \& Wood 1901-1918; Kozłowski 1948; Crowther 1978). As the reproductive strategies employed in these groups differ considerably, no small part of the discussion of their 
systematic position focussed on the interpretation of rare, attached, putatively sac-like appendages (e.g. Nicholson 1872; Ulrich \& Ruedemann 1931).

\subsection{0-1870: sac-like appendages and 'graptogonophores'}

Graptolites bearing sac-like appendages have been known since the 1850s, but due to "various [unspecified] accidental difficulties" (Logan in Hall 1865 and references therein) illustrations were not published until the next decade. Hall (1865) proposed that these appendages were reproductive bodies similar to hydrozoan gonothecae, and suggested that graptolites were closely related to the sertularians. It seems Hall's work captured the imagination of the young H. Alleyne Nicholson: Hall's monograph was likely used by Nicholson to aid the identification of the graptolites he collected in the Southern Uplands. Indeed, Nicholson $(1866,1872,1873)$ regularly referred to Hall's work on graptolite reproduction.

Whilst collecting the Silurian strata of the Southern Uplands in the summer of 1866, Nicholson discovered a variety of discoidal and ovato-triangular fossils associated with graptolites (e.g. Fig 2). Though not found attached to graptolites themselves, these fossils resemble the supposed reproductive organs described by Hall (1865), and Nicholson (1866) argued that they represented graptolite ovarian vesicles which had detached from their parent colony, and called them 'graptogonophores'. He supported Hall's argument for a hydroid affinity for the graptolites, suggesting that the concentrically 'ribbed' discoidal specimens represented vertical compressions of a sertularian-like graptogonophore, and that the ovato-triangular specimens were preserved in profile. Nicholson supported his interpretation by illustrating several examples where the discoidal and ovatotriangular specimens were closely associated with graptoloids (e.g. Fig 1c). 
However, this work was controversial, drawing a vociferous reply from William Carruthers who argued that the associations of the supposed graptogonophores with graptolites were no more than fortuitous juxtapositions, and that the discoidal specimens most likely represented the brachiopod Siphonotreta micula (Carruthers 1867a). This precipitated a lengthy correspondence, with Nicholson (1867a, 1867b, 1867c, 1868b) arguing that graptolites were hydrozoans, largely on the basis of their reproductive strategy, whilst the more vehement Carruthers (1867b, 1867c, 1868a, 1868b) stated that considerations of zoological position should be based on 'normal' characters such as colony construction rather than on rare and ambiguous evidence. The latter felt that whilst graptolites were closely allied to the Hydrozoa, they also shared characters with the Polyzoa. As much by perseverance as by any tendency to provide new information, Nicholson's view that graptolites were extinct hydrozoans became more widely accepted. Nicholson's work subsequently focussed more on corals than graptolites (see Benton 1979); and, at this time, graptolite research itself also moved away from more theoretical discussions of their affinity with workers such as Lapworth focussing on the more practical concerns of taxonomy and biostratigraphy (e.g. Elles \& Wood 1901-1918; Oldroyd 1990; Rushton 2001).

\subsection{0-1900: Graptolite reproduction and “Dawsonia” Nicholson}

Nicholson's theory of graptolite reproduction supposed that once sufficiently mature, the 'graptogonophore' detached itself from its connection with the parent colony and became a free-swimming zooid (Nicholson 1868a). This assertion was supported in part by evidence for the co-occurrence of 'graptogonophores' and graptolites furnished with ramifying fibres (e.g. Fig. 1f) in the same strata (Nicholson 1872). 
Nicholson (1873) noted that there were several distinct types of graptogonophore in the Ordovician Lévis Fm. at Point Lévis, Quebec. As it would be almost impossible to relate these back to the individual graptolite species they came from, he referred them to the form genus "Dawsonia", much in the manner that one names ichnotaxa independently of the animal that constructed them. Nicholson (1873) named four species: “D." acuminata, "D." rotunda, "D.” tenuistriata, and “D." campanulata. Gurley (1896), also working in Point Lévis, added two further species: “D." monodon and "D." tridens.

These species have disparate temporal and geographical ranges. " $D$." campanulata is only known from Early Silurian strata of the British Isles (Nicholson 1873; Lapworth 1876, 1876-7; Marr \& Nicholson 1888; Peach \& Horne 1899; Williams 1981, 1996), though it occurs in both Laurentia (in Moffatdale, Scotland, and Coalpit Bay, Donaghadee, Northern Ireland) and Avalonia (the English Lake District), which were on either sides of the Early Palaeozoic Iapetus Ocean at this time. “D." rotunda and “D." tenuistriata are only found in the Ordovician Quebec Group at Point Lévis, Canada (Nicholson 1873), and Gurley's species have only been recorded in the Ordovician of North America at Point Lévis, Quebec, and the Deep Kill, near Melrose, New York (Ruedemann 1904, 1934; Vannier et al. 2003). However, “D." acuminata appears to be more cosmopolitan, with Nicholson (1873) stating that it occurs at both Point Lévis, Canada, and in northern England. Nicholson (1873) noted that his concept of "D." acuminata was similar to "D." campanulata in both stratigraphic range and form, though he acknowledged that its outline was notably more triangular and its mucro (proximal termination) less sharply delineated. Nicholson (1873) believed that his localities in the UK and Canada were contemporaneous and of similar age to graptolites bearing sac-like appendages (Hall 
1865, Nicholson 1872), though graptolite biostratigraphy now reveals this to be untrue (cf. section $6 \&$ refs in Fig 5a). However, in the 1870s the age of the strata in the Southern Uplands sections was somewhat of an enigma (Oldroyd 1990; Rushton 2001), making correlation with North American sections problematic.

\subsection{Twentieth century work on graptolite reproduction}

The $20^{\text {th }}$ century saw graptolite reproduction become a less prevalent area of research, and since a pterobranch affinity for graptolites has been clearly demonstrated (Kozłowski 1947, 1948; Towe \& Urbanek 1972; Crowther 1978), Nicholson’s work has become largely overlooked. However, biserial graptoloids with sac-like appendages unquestionably attached to their rhabdosome continued to be described as reproductive structures in the early twentieth century (e.g. Elles 1940). Likewise, Ulrich and Ruedemann (1931) reported dendroid graptolites with swollen, oval appendages purportedly homologous with bryozoan ooecia. However, these correspond to bithecae in terms of position and arrangement, and the specimens are too poorly preserved to discern their precise nature (Kozłowski 1948).

The discovery of eggs and embryos inside the autothecae of benthic graptolites (Kozłowski 1948; Bulman \& Rickards 1966) led to a reinterpretation of sac-like appendages in graptolites. Kozłowski (1948) considered Hall's supposed 'egg sacs' to be chitinous envelopes associated with the zooids, though he did not speculate on their function, whilst Bulman (1964) figured several similar specimens in an early discussion of graptolite hydrodynamics. Similarly, more recent discussions of graptolite reproduction have overlooked these and other supposed reproductive organs (e.g. Crowther 1978; Hutt 1991; Underwood 1993). For example, the branching appendages described in Ruedemann (1936) were thought to represent epibionts 
(Kozłowski 1948). The swollen, oval appendages documented by Ulrich and Ruedemann (1931) might also be epibionts: Kozłowski (1965) showed that Cephalocystis graptolithifilius, a similar structure found on other graptolites, is in fact a cephalopod egg capsule comparable to those of the recent Sepia officinalis which encrusts the sea grass Zostera. Similarly, Underwood (1993) suggested that the putative cases of connection between graptogonophores and graptolites, as illustrated by Nicholson (1866), could plausibly represent parasitic outgrowths or epizoans colonising a graptolite 'benthic island' sensu Kaufmann (1978).

However, these and other examples of sac-like graptoloid appendages (e.g. Fig $1 \mathrm{~d}, \mathrm{f}$ ) are certainly distinct from the unambiguous parasites figured by Bates and Loydell (2000), but are superficially similar in form and preservation to " $D$." campanulata and "D." acuminata. As such they require re-examination. Since Kozłowski's influential work 'graptogonophores' have generally been described as sac-like or vane-like appendages with little comment as to their function (e.g. Bulman 1964; Koren’ \& Rickards 1997).

\subsection{A pterobranch-like model for graptolite reproduction?}

Since scanning electron microscopy has been employed for studies of graptolite ultrastructure (e.g. Towe \& Urbanek 1970; Crowther 1978, 1981), an affinity for graptolites with the pterobranch hemichordates has become widely accepted (e.g. Dilly 1993; Cameron 2005; Maletz et al. 2005). As such, recent discussions of reproduction in graptolites (e.g. Hutt 1991) have been premised on the belief that graptolites adopt pterobranch-like mechanisms (cf. Gilchrist 1915; Stebbing 1970). The pterobranchs Rhabdopleura and Cephalodiscus reproduce both sexually and asexually (Hutt 1991). Though most zooids in $R$. compacta are neuter or sexually 
immature, certain zooids may metamorphose and develop either an ovum or testis (Stebbing 1970). Whilst the sexes are separate in Rhabdopleura, certain species of

Cephalodiscus colonies may be hermaphroditic, with certain zooids bearing both male and female reproductive organs (Horst 1939, Bulman 1970). Though its colonies are sessile and its zooids have limited movement, Rhabdopleura undergoes internal fertilisation, with its oviduct serving only as a conduit for sperm to reach the ova (Stebbing 1970). In both Rhabdopeura and Cephalodiscus, clutches of embryos remain in the creeping tube until they mature as ciliated, lecithotrophic larvae (Dilly 1973; Lester 1988a). The larva leaves the creeping tube as a free-swimming individual which secretes a collagenous, dome-shaped prosiculum (Dilly 1973; Dilly \& Ryland 1985). Later, the larva metamorphoses under the prosiculum and emerges as a juvenile (Dilly \& Ryland 1985; Lester 1988b) that settles on the substrate and later asexually buds to form a colony (Stebbing 1970; Dilly 1973).

Though there is little direct evidence of reproduction in the graptolite fossil record (cf. Hutt 1991), eggs and embryos have been reported in certain specimens (Kozłowski 1948; Bulman \& Rickards 1966). This would be consistent with graptolites producing a free-swimming lecithotrophic larva, that later secretes a prosicula (equivalent to the pterobranch prosiculum) in the plankton before maturing (cf. Williams \& Clarke 1999) and budding to form a colony.

\subsection{Historical interpretations of "Dawsonia” Nicholson}

\subsection{1 “D.” monodon, “D.” tridens, “D.” acuminata, and “D.” campanulata:} crustaceans, molluscs or algae? These mucronate species have received more attention than the other species, which are dealt with below. "D." monodon and " $D$." tridens were originally described by Gurley (1896), but have long been considered to 
be tail-pieces of the crustacean Caryocaris (Ruedemann 1934; Rolfe in Theokritoff 1964). Rolfe (1969, p. 316) stated that "Dawsonia" is a junior synonym of Caryocaris Salter (1863), but did not re-examine Nicholson's material (Ian Rolfe, pers. comm.). Though "D." acuminata has all but vanished from the literature, "D." campanulata is often used.

Lapworth (1876-77) considered "D. " campanulata to be a member of the crustaceans in his catalogue of fossils from western Scotland, perhaps due to its similarity and common co-occurrence with the putative crustaceans Aptychopsis Barrande (1872), Peltocaris Salter (1863), and Discinocaris Woodward (1866) (Lapworth 1876, 1876-77; Marr \& Nicholson 1888; Peach \& Horne 1899). These putative crustaceans look similar to certain "Dawsonia" species: disarticulated valves of Peltocaris and Aptychopsis are similar to "D." campanulata in outline, and Discinocaris has an ornament similar to that of “D." rotunda and "D." tenuistriata. However, none of the "Dawsonia" material examined in this study bears the characteristic dovetail symmetry that characterises complete specimens of these other taxa. Gürich (1928) also compared “D." campanulata to Peltocaris, which he considered to be the covers of a hyolithid or chiton-like organism. However, this work offered no firm conclusions as to the affinities of "Dawsonia" and we have found no evidence of either hyolithids or chitons co-occurring in the same strata as it.

The affinities of Aptychopsis, Peltocaris, and Discinocaris remain uncertain. Rolfe (1969, p. 328) noted that "they have been compared and confused with graptolite 'swim bladders' and 'gonangia', eurypterid metastomata, hyolith opercula, polyplacophoran plates, bivalves, arthodire dermal plates, and branchiopod carapaces," and he noted there was no evidence to support an affinity for either Aptychopsis, Peltocaris, or Discinocaris with the phyllocarids. Rolfe (1969, pp. 328- 
329) suggested that these taxa may perhaps represent the aptychi of soft-bodied cephalopods rather than being crustacean carapaces. However, he did not go as far as synonymising Aptychopsis, Peltocaris, and Discinocaris with the aptychus morphogenus Sidetes Giebel sensu Moore \& Sylvester-Bradley (1957).

There is no good reason to group "D." campanulata with these supposed aptychi. Indeed, neither Gürich's (1928) work nor a crustacean affinity gained serious consideration in the most recent re-examination of " $D$." campanulata, which tentatively reinterpreted it as an alga (S.H. Williams 1981).

\subsection{2 “D." rotunda and “D.” tenuistriata: possible brachiopods? Neither " $D$.”} rotunda nor "D." tenuistriata are mucronate: together they form a group of small, subcircular shelly-fossils. Though Nicholson (1873) stated that “D." rotunda and “D." tenuistriata appeared too variable in form and appearance to be inarticulate brachiopods, this assertion was questioned from the outset (Carruthers 1867a; Ruedemann 1904, 1934). More recently, Benton (1979) noted that some of the Nicholson's type material may be small brachiopods.

1.5.3 Misdiagnoses. Several incompatible forms have been erroneously assigned to "Dawsonia" Nicholson principally because little or no reference was made to the type specimens. As Benton (1979) noted, the trace fossil Lockeia U.P. James was misdiagnosed as “Dawsonia” by U.P James's son, J.F. James (1885, 1892). As "Dawsonia" is preserved as a body fossil, this name clearly cannot be applied to a trace fossil (Häntzschel 1965, 1975; Osgood 1970). However, the name “Dawsonia cycla" is still used for another fossil from the Cincinnati area which consists of small, black, shiny discs that are found encrusting the surfaces of nautiloid conchs. Though 
Frey (1989) thought that these discs may represent the attachment sites of the dendroid graptolite Mastigograptus, they are now thought to represent the epibiont Sphenothallus (Neal \& Hannibal 2000).

\subsection{The current status of "Dawsonia” Nicholson}

The name "Dawsonia" is still widely used by graptolite workers (e.g. Williams 1996), though now it is almost exclusively used as shorthand for "D. " campanulata, which is its type species (Miller 1889). No consensus as to its taxonomic status or systematic position has yet emerged. Though the genus "Dawsonia" was conceived to describe the egg sacs of a sertularian-like hydroid, this name has been applied to unrelated fossils from all of the major divisions of the bilateria. Its type species, " $D$." campanulata was most recently interpreted as an alga (Williams 1981). Dawsonia Nicholson is junior homonym of the trilobite Dawsonia Hartt in Dawson (1868). With all the above in mind, Nicholson's genus is in need of taxonomic revision.

\section{Material and methods used in this study}

\subsection{Nicholson's types and comparative material}

Much of Nicholson's type and figured material is housed in the Natural History Museum [NHM], London, which purchased a collection of 1400 graptolites from

Nicholson in 1883 (Benton 1979). The unfigured portion of Nicholson's collection remains in the Aberdeen University Geology Department, and is catalogued in Benton and Trewin (1978). Nicholson's material from the Lake District lies in the Harkness and Marr collections of the Sedgwick Museum, Cambridge [SM]. 
The type material of "Dawsonia" Nicholson, as recognised by Benton (1979) is in the G.J. Hinde collection of the NHM. It has been re-examined and reaccessioned as part of this study. Nicholson did not identify any specimens from UK strata in this collection as " $D$." acuminata, despite mentioning its occurrence in northern England (Nicholson 1873). Given that Nicholson's illustrations are often idealised woodcuts taking features from several specimens (Benton \& Trewin 1978), it has been impossible to precisely determine his type specimens. However, as Nicholson's diagnoses can be recognised from his distinctive handwriting on the manuscript specimen labels (Fig 2n,o), we have assigned lectotypes for each of his four species. "D." campanulata remains the type species of the genus (secondary diagnosis, Miller 1889 contra Ruedemann 1904, 1934). Other comparative material is housed in the British Geological Survey [BGS] collections at Keyworth, near Nottingham, the Ulster Museum, Belfast [BEL] and in the Lapworth Museum, University of Birmingham [BU].

In order to compare "Dawsonia" with the sac-like appendages of graptolites, we undertook an extensive search of museum holdings and appropriate literature. “D. ” campanulata-bearing localities in Moffatdale, southern Scotland, and the Lake District of England were also recollected to provide an unbiased sample of this species. We were unable to collect field specimens of graptolites bearing sac-like appendages, perhaps due to their relative rarity, and we rely entirely on museum collections for such graptolites.

In addition to the occurrences of "Dawsonia" noted in section 1.2 and above, Ruedemann (1904, p. 734) commented that “[ "D." campanulata] is very common in the Trenton (Normanskill) graptolite shales of New York and Canada." However, we have not been able to identify this fossil amongst Ruedemann's original collections, 
although there are plenty of graptolites bearing 'graptogonophores' in his material. In addition, Ruedemann (1908) reported that in 1889, H.M. Ami named three new species of "Dawsonia" from graptolitic strata in the St Lawrence region of Canada. However, we have been unable to find any trace of Ami's "Dawsonia" species in either the literature or in museum collections. Likewise, we have been unable to find Gurley's type specimens of "D." monodon and "D." tridens. Though they were once held in the collections of the New York State Museum, Albany, NY [NYSM] (Ruedemann 1934 \& references therein), they are no longer in its possession. When Ruedemann (1904) illustrated “D." monodon and "D." tridens specimens from NYSM collections, he chose examples from the Quarry at the Deep Kill, near Melrose, New York, only copying Gurley's drawings of the Point Lévis material. This suggests that they were not in the NYSM at that time either. It may be that the specimens went missing at the very end of the 1800 s when a long-term budget deficit led James Hall to sell many specimens to keep the Geological Survey and State Museum afloat (Ed Landing, pers. comm. 2004).

Though Ruedemann's $(1904,1934)$ material has been re-examined for comparative purposes, neither those specimens nor Nicholson's Point Lévis specimens clearly preserve the carapace. Given that Caryocaris taxonomy is primarily based on carapace morphology, we are unable to determine whether Ruedemann's specimens are truly synonymous with Gurley's species. As such, this paper focuses on clarifying Nicholson's concept of the "Dawsonia" species, rather than entering the more nebulous realm of phyllopod systematics.

\subsection{Methods used and terminology employed}


All fossils have been studied under reflected light microscopy. Additionally, uncoated specimens were examined at $15 \mathrm{KV}$ in backscatter mode in Hitachi S-3600N and LEO 435VP SEMs, with phases identified using energy dispersive X-ray analyses (EDS) using Oxford Instruments INCA and ISIS software, respectively. The electron microscope techniques used closely follow those described in Martill et al. (1992) and Orr et al. (2002). Illustrated images have been digitally enhanced to increase the contrast between fossil and matrix.

Details of repositories and specimen numbers are listed with the appropriate figures and in the systematic section; details of the criteria used in the morphometric analysis are given in Figure 5. As the brachiopod taxa were often incomplete, morphological measurements were taken on well-preserved growth-lines as well as on outlines, though in each case these are clearly distinguished in the appropriate figure caption. All measurements were made on camera lucida drawings of x40 or x50 optical magnification, and recorded to an accuracy of greater than one percent.

Morphological terms used in systematic descriptions are as employed in Holmer \& Popov (2000) for the brachiopod species, in Rachebouef et al. (2000) and references therein for the Caryocaris tail-pieces, and defined in Figure 5 for " $D$." campanulata. Because Nicholson's Point Lévis material consists entirely of disarticulated specimens, we have used morphological criteria to assess which forms could plausibly conjoin based on the present understanding of inarticulate brachiopods and Caryocaris in order to avoid unnecessary taxonomic inflation. Abbreviations used in the synonymy lists are those of Matthews (1973) and the qualifiers used in open nomenclature may be found in Bengtson (1988). 


\section{The nature of “Dawsonia” Nicholson}

It is clear that "Dawsonia" is polyphyletic. The lectotype of " $D$. " acuminata is a furcal ramus from the tail-piece of the crustacean Caryocaris acuminata (Fig. 4). Other fossils within the fauna include telsons and carapace fragments which are considered conspecific given the present understanding of Caryocaris morphology (Fig. 4d). The lectotypes of “D." rotunda and "D." tenuistriata are linguliform brachiopods (Fig. 3c,d) and have been tentatively re-assigned to the genera Acrosaccus and Paterula respectively, and Nicholson's type collection also contains a form provisionally identified as Discotreta $\mathrm{cf}$. levisensis (Fig. 3f). As no articulated specimens are present we cannot unambiguously determine which shells articulated in life. However, two of the four discrete shell morphotypes shown in Figure 5c have indistinguishable outlines (with $\mathrm{W} / \mathrm{L} \sim 1$ ) and probably represent an unequivalved species. The other two shell morphotypes could not plausibly co-join (cf. Fig 5c), consistent with there being three species present in the collection. The systematic palaeontology of these taxa is dealt with in section 6 .

The style of preservation of the above listed dawsoniids is different from the graptolites which co-occur in the Point Lévis fauna, suggesting that they were originally composed of non-graptolitic material. The graptolites are preserved as dull, black compressions, whereas the dawsoniids are generally in relief, having a horny texture and some having a bronze, pyritous sheen. EDS analyses of the Point Lévis dawsoniids specimens reveals that they are preserved as phosphate with some associated pyrite (Fig. 6f,g). This composition is consistent with these taxa being linguliform brachiopods and caryocarid arthropods rather than graptolites, which are carbonaceous. Therefore, these species of "Dawsonia" are reassigned to their 
appropriate clades and can be discounted from any consideration of graptolite reproduction.

Though Nicholson (1873) mentioned the occurrence of “D." acuminata in English strata, we have been unable to identify it in UK collections. Morphometric analysis reveals that there is some overlap between " $D$." campanulata and $C$. acuminata (Fig. 5b, d). However, even the most slender “D." campanulata can be clearly distinguished from C. acuminata by the presence of a delineated mucro, its rounded latero-distal margin (Fig. 3), and its composition (Fig. 6a-d). It therefore seems most likely that Nicholson was either referring to slender "D." campanulata morphotypes as "D." acuminata, or he was perhaps confusing the tail-pieces of Caryocaris wrighti which occur in strata of the British Isles (Rushton \& Williams 1996; Vannier et al. 2003) with C. acuminata. To avoid unnecessary confusion, we have included Nicholson's so-called “D.” acuminata from the British Isles within our amended definition of “D." campanulata, with C. acuminata only referring to his Canadian material.

There is little similarity between "D." campanulata and Caryocaris tail-pieces (cf. Figs 1 \& 4), or indeed with the Point Lévis dawsoniids, the most notable differences being in its composition and outline. It is preserved as an organic compression (Fig 6a-d) unlike Caryocaris, which is preserved in phosphate (Fig 6g). It is more symmetrical than either the carapace or furcal ramus of a Caryocaris, and notably more ovate than the Caryocaris telson. Its mucro is too centrally positioned to represent either an anterior horn or a postero-dorsal spine of the Caryocaris carapace, and it differs from the marginal spinules of the Caryocaris ramus in terms of size and position. Unlike a furcal ramus, the "body" of " $D$. ” campanulata is ovato-triangular rather than ovato-parallelogrammic, and it lacks a serrated lateral margin. Though 
lacking a mucro, the grossly teardrop form of the Caryocaris telson is similar in shape to the "body" of "D." campanulata. However, morphometric analysis (Fig. 5d) reveals no overlap between Caryocaris telsons (where D/L $<0.2$ ) and "D." campanulata (where $0.2<\mathrm{D} / \mathrm{L}<0.6$ ).

Though "D." campanulata shares a similar preservation style to the sac-like appendages seen in graptolites (Fig. 6a-e), there is no evidence to support a homology. Whilst both are found as silvery organic films in the black shales of the Southern Uplands, “Dawsonia” cannot be recognised as a graptolite (Bulman 1970). Morphometric analysis reveals that the similarity between the two is superficial, with the graptolite appendages having a consistently more distal centroid (Fig. 5a). They are also more asymmetrical and more variable in their form than "D." campanulata, and there is no discrete transition between their connecting rods and their lobate distal part, which is quite unlike the transition between the mucro and the lobate "body" in “D.” campanulata. Though “D.” campanulata may be found in close association with graptolites, it is not attached to them; instead, they may be merely juxtaposed (e.g. Fig 1c). Neither is there any good evidence to suggest that "D." campanulata is a sac-like appendage broken from a graptolite. For one thing, its mucro tapers to a narrow point, rather than having a blunt or irregular end. Indeed, the connecting rod and margins of the sac-like graptolite appendage seem unlikely to break readily. They are well-defined in most specimens, having a similar mode of preservation to the nema. This suggests they are recalcitrant tissues and may have possessed a noticeable elasticity: Crowther (1978) noted that the nema displays a certain 'springiness' in acid-isolated specimens. In summary, there is no evidence for " $D$. " campanulata being a graptolite egg-sac, or for it being related to graptolites at all. 
A concentric, raised, nipple-like structure occurs in several specimens of " $D$." campanulata (e.g. Fig. 2f) and has previously been interpreted as evidence for it having originally had a hollow body (Williams 1981). Nicholson (1872, 1873) believed that this 'nipple' represented compression of a hollow three-dimensional egg-sac onto its more rigid mucro. However this does not appear to be the case, as many specimens reveal both a mucro and a 'nipple' (e.g. Fig 1c), and some specimens show that "Dawsonia” may only partially overlap a 'nipple' (Fig . 6e). Instead, SEM investigation reveals the nipples to be composed of diagenetic pyrite adopting a rounded and concentric habit (cf. Allison 1988; Underwood \& Bottrell 1994). As such, the 'nipple' is best considered to be a product of compression of "Dawsonia" onto pyrite formed in early (?pre-compaction) diagenesis, rather than an intrinsic part of the fossil.

Detailed examination of the sac-like appendages of Hallograptus bimucronatus reveals that concentric lines are also present in them (Fig. 1f), crossbracing better preserved margins. However, they are consistent with being the remnants of fusellar structures like those seen in the Orthoretiolites hami scopula (Bates \& Kirk 1991). Such a mode of fabrication would deny the possibility that these structures formed a housing from which an 'egg-sac' could easily detach as Nicholson (1868a, 1872) suggested. Nicholson believed that “D.” campanulata represented a graptolite egg-sac that became a free-swimming entity, supposing that it was hollow and filled with eggs whilst housed in a cup of ramifying fibres connected to the graptolite. He proposed that this 'ovarian vesicle' slid out once it was able to swim freely. However, if Hallograptus constructed its appendages in a manner comparable to the scopula of $O$. hami, it would represent a plate-like, rather than cup-like, structure (cf. Bates \& Kirk 1991). 
Indeed, it is doubtful whether sac-like graptolite appendages represent eggsacs. The preponderance of these features in scalariform preservation suggests that they originated from the interthecal wall rather than connecting the thecae per se, so there is no direct evidence for their intimate connection with the zooid itself. Moreover, their regularity of form is inconsistent with what one would expect of an unambiguously vesicular structure such as the Climacograptus wilsoni vesicle (Williams 1994). Given that these structures are only known in the biserial graptolites, it seems unlikely that they are related to graptolite reproduction.

\section{Discussion}

Nicholson remains one of the great early graptolite workers, despite being wrong in his views of graptolite reproduction (Nicholson 1866, 1872, 1873, etc.). It was not until Clupáč (1970) discovered well-preserved caryocarids in limestone nodules from the Ordovician of Bohemia that the morphology of their tail-piece was fully understood; hence, it is understandable that Nicholson (1873) did not recognise " $D$." acuminata as such, despite recognising Caryocaris carapaces in the Point Lévis fauna. Nicholson's assertion that " $D$." rotunda and “D." tenuistriata were not brachiopods appears at odds with his (1867a) claim that "it is impossible that any palaeontologist, possessed of ordinary powers of observation, should fall into an error so gross [as to fail to recognise an inarticulate brachiopod]".

Noting the variability of form within "D." tenuistriata, for example, Nicholson (1873, p. 142) argued that describing the species as egg-sacs allowed for greater morphological plasticity, otherwise "we should have to believe there were four 
or five distinct species of brachiopods in these beds which is very unlikely" (the information in Benton (1979) confirms that Nicholson was not accustomed to such faunal diversity in UK sections). It appears that he conflated the beak of the brachiopods with the variably positioned "nipple" of "D." campanulata (e.g. Fig. 2), a false homology that underpinned his "Dawsonia" concept. So, in an age before taphonomy and palaeoenvironment were generally considered, when many species were only known from disarticulated fragments, Nicholson explained the vagaries of variable preservation and differing morphology in a strikingly diverse fauna by appealing to his theory of graptolite reproduction.

\section{Conclusions}

There is no evidence to support the notion that "Dawsonia" is related to graptolite reproduction. Likewise, there is no strong case for sac-like appendages on graptolites having a reproductive function, given the discovery of eggs and embryos in the thecae of benthonic graptolites, and our knowledge of reproduction in the pterobranchs (Kozłowski 1948; Bulman \& Rickards 1966; Stebbing 1970; Dilly 1973; Hutt 1991). As such, the function of these sac-like appendages remains enigmatic, and these, along with the function of synrhabdosomes, should be re-examined in order to assess what, if any role either plays with regard to graptolite reproduction.

All known species of "Dawsonia" have been reassigned to valid genera except "D." campanulata, which is best considered a problematicum. "D." acuminata Nicholson, “D." tridens Gurley and “D.” monodon Gurley represent the tail-pieces of Caryocaris acuminata (Nicholson 1873). We suggest that C. monodon 
(Gurley) should not apply to specimens from Point Lévis (contra Ruedemann, 1934). “D. " rotunda Nicholson is tentatively reassigned to the brachiopod genus Acrosaccus, and “D." tenuistriata Nicholson is accommodated by the brachiopods ?Paterula tenuistriata and Discotreta $\mathrm{cf}$. levisensis (Walcott 1908). The trace fossil misdiagnosed as Dawsonia Nicholson by J.F. James $(1885,1892)$ has long been known to represent the trace fossil Lockeia U. P. James (1879) (see Benton 1979), whilst "Dawsonia cycla" most likely represents the epibiont Sphaenothallus (Frey 1989; Neal \& Hannibal 2000).

“D. " campanulata is a problematicum, currently being investigated by the authors. Though Dawsonia Nicholson is an invalid generic name, it would be premature to formally re-describe it until further information pertaining to the affinity of "D." campanulata is available. That nobody has provided a more definite idea of what "D." campanulata may represent in the hundred years since Nicholson's early death can be taken as a minor tribute to the man who clearly recognised its uniqueness.

\section{Systematic Palaeontology}

Phylum Arthropoda, von Siebold \& Stannius, 1845

Superclass Crustacea Pennant, 1777

Class Malacostraca Latrielle, 1806

Subclass Phyllocarida Packard, 1879

Order Archaeostraca Claus, 1888

Family Caryocarididae Racheboeuf, Vannier \& Ortega, 2000 
Genus Caryocaris Salter 1863

* 1863 Caryocaris n. gen. Salter, p. 139.

non 1868 Dawsonia Hartt in Dawson, p 655.

p. 1873 Dawsonia Nicholson, pp. 139-140 pars.

1896 Dawsonia Nicholson; Gurley, p. 88.

1904 Caryocaris Salter; Ruedemann, pp. 738-742.

1969 Caryocaris Salter; Rolfe in Moore, p. 316.

2000 Caryocaris Salter; Racheboeuf, Vannier \& Ortega, pp. 322-323.

Remarks. The synonymy above is in addition to the detailed list in Racheboeuf, Vannier \& Ortega (2000). In the absence of a carapace, a tail-piece consisting of elongate, leaf-shaped furcal rami and a shorter, narrow triangular telson is sufficient to diagnose the genus (Racheboeuf, Vannier \& Ortega, 2000, p. 328).

Caryocaris acuminata (Nicholson 1873)

(Figures 4 \& 6g)

vp. 1873 Dawsonia acuminata n. gen. et n. sp. Nicholson, pp. 140-141, Figs 3a-a' pars.

v. 1873 Caryocaris sp. Nicholson, p. 143.

1896 Caryocaris oblongus n. sp. Gurley, p. 87, Pl. 4, Fig. 2.

p. 1896 Caryocarus [sic] curvilatus n. sp. Gurley, pp. 87-88 pars, ?Pl. 4, Fig. 3, ?P1. 5, Fig. 3.

1896 Dawsonia monodon n. sp. Gurley, p. 88, P1. 5, Fig. 4. 
1896 Dawsonia tridens n. sp. Gurley, p. 88, Pl. 5, Fig 5.

non 1904 Caryocaris cf. curvilineatus [sic] Gurley; Ruedemann, p. 738, Pl. 17,

Fig. 17.

non 1904 Caryocaris cf. oblongus Gurley; Ruedemann, p. 738, Pl. 17, Figs 14-16.

p. 1904 Dawsonia tridens Gurley; Ruedemann, p. 741 pars, ?Pl. 17, Fig. 18, non

Pl. 17, Figs. 19-20 [=C. monodon].

p. 1904 Dawsonia monodon Gurley; Ruedemann, pp. 741-742 pars, Fig 105,

?P1. 17, Figs 21-23, non P1. 17 Figs 24-26 [=C. monodon].

non 1934 Caryocaris curvilata Gurley; Ruedemann, p. 92, P1. 22, Figs 1-9.

p. 1934 Caryocaris monodon (Gurley); Ruedemann, p. 93-95 pars, non Pl. 22,

Figs 10-14.

Type material. NHM P1985.3 lectotype (furcal ramus).

Additional material. Syntypes NHM P1977, P1982.1-3, P1984.1-2, P1985.3-5, P1988.3: 0 complete carapaces; 8 incomplete carapace fragments; 0 articulated tail-pieces; 11 well-preserved furcal rami; 7 telsons; 15 poorly-preserved or fragmentary furcal rami, telsons and indeterminate fragments.

Type locality. Lévis Shale, Point Lévis, Quebec, Canada. Lévis Formation, Ordovician (Arenig).

Diagnosis. Carapace outline indeterminate; linear corrugated ornament on fragments. Tail-piece with narrow triangulate telson lacking ridge or carina; furcal rami elongate, leaf-shaped, ca. 1.5 times longer than telson on average, with acuminate distal margin, bearing large, triangular, posteriorly-directed spines along their outer margin; distinctive narrow ridge and furrow adjacent to its proximal inner margin along its proximal third. Telson ranges from 1.8-2.9 $\mathrm{mm}$ in length and 0.9-1.5 
$\mathrm{mm}$ in width. Furcal ramus ranges from $2.7-6.1 \mathrm{~mm}$ in length and $1.3-2.5 \mathrm{~mm}$ in width; smaller specimens may have two marginal spines (e.g. Fig. 4b), larger specimens are stouter and more asymmetrical and have three marginal spines (e.g. Fig. $4 a, 6 g)$

Remarks. Until the morphology of its carapace is better known, $C$. acuminata should remain a species separate from C. monodon and other caryocarids. C. acuminata refers exclusively to caryocarids from Point Lévis and C. monodon refers to caryocarids from the exposure at the Deep Kill at Melrose, as laid out in the synonymy above. Though the outline of the tail piece is similar in both localities, the morphology of the tail-piece alone is not well enough placed in the hierarchy of characters to determine synonymy at a species level (Racheboeuf, Vannier \& Ortega 2000, p. 328). The variation in number of marginal spines may represent allometric growth (cf. Rushton \& Williams 1996); however, small spines may not necessarily be apparent on poorly preserved specimens (see Fig. 4b).

As the type specimens of $C$. oblongus Gurley, "D." monodon Gurley and “D.” tridens Gurley are presumed lost, Nicholson's material assumes topotype status. Therefore, these species can be suppressed as junior synonyms. This is supported by comparison with Gurley’s original descriptions and illustrations: “D. ” tridens corresponds exactly with our observations on the furcal ramus of C. acuminata, whilst “D." monodon most likely represents an articulated Caryocaris tail-piece preserved in lateral view. C. oblongus presumably represents the fragments of a carapace. Nicholson (1873) also noted Caryocaris carapace fragments in the Point Lévis fauna. Similarly, Caryocarus [sic] curvilatus, described as an aberrant graptolite in Gurley (1896), is most likely an articulated abdomen and tail-piece. Likewise, we wholeheartedly concur with Ruedemann $(1904,1934)$ that " $D$." 
monodon and " $D$." tridens represent parts of a crustacean rather than being unusual graptolites.

Though no articulated specimens are present in Nicholson's collection, it seems more parsimonious to describe the disarticulated parts as one species rather than several. Nicholson described "D." acuminata prior to mentioning the specimens which he referred to Caryocaris sp. As such, there seems little controversy in retaining the specific name acuminata, which refers to the pointed end of the furcal ramus.

Phylum Brachiopoda Duméril, 1806 Subphylum Linguliformea Williams et al., 1996 Class Lingulata Gorjansky \& Popov, 1985

Remarks. We place the three species of brachiopods from Nicholson's Point Lévis material within the Lingulata on the basis of their organophosphatic composition, rudimentary articulation and larval shells. As noted above, many authors have considered them to be brachiopods, though they have not been formally assigned to the phylum until now.

Order Lingulida Waagen, 1885

Superfamily Linguloidea Menke, 1828

Family Paterulidae Cooper, 1956

Genus Paterula Barrande, 1879

non 1868 Dawsonia Hartt in Dawson, p. 655. 
p. 1873 Dawsonia Nicholson, p. 139-140 pars.

* 1879 Paterula n. gen. Barrande, Pl. 110.

2000 Paterula Barrande; Holmer \& Popov, 2000, p 75.

Paterula? tenuistriata (Nicholson 1873)

(Figure 3c,e)

vp. 1873 Dawsonia tenuistriata Nicholson, pp. 141-142 pars, Figs 3 c-d'.

Type material. Lectotype: NHM P1984.3 (part), P1984.2 (counterpart).

Additional material. NHM P1984.1-3, P1985.3 (5 valves).

Type locality. Lévis Shale, Point Lévis, Quebec, Canada. Lévis Formation, Ordovician (Arenig).

Description. Shell with elongate oval outline, convex. Apex and limbus submarginal to subcentral. Anterior-posterior valve length $1.4->3.4 \mathrm{~mm}$, valve breadth 1.2-3.7 mm, typical specimen breadth $>2 \mathrm{~mm}$; length-width ratio 1.2-1.5, typically 1.35; maximum breadth at anterior-posterior midpoint. Growth lines continuous and fine, equally prominent, regular $0.04-0.1 \mathrm{~mm}$ spacing throughout the valve.

Remarks. Though this genus is typically unequivalved, only a single valve is present in Nicholson's collections. As Dawsonia Nicholson is an invalid taxon there is no conflict of names. While there is some similarity between this form and the younger taxon $P$. cf. portlocki Geinitz (1852) as illustrated by Henningsmoen in Waern et al. (1948), the material described herein is too poorly preserved to properly compare the taxa. As such, Nicholson's collections need to be supplemented with 
additional material exhibiting the shell's internal view before this taxon can be precisely placed. Therefore, we have kept the taxon in open nomenclature.

Superfamily Discinoidea Gray, 1840

Family Discinidae Gray, 1840

Genus Acrosaccus? Willard, 1928

non 1868 Dawsonia Hartt in Dawson, p. 655.

p. 1873 Dawsonia Nicholson, p. 139-140 pars.

* 1928 Acrosaccus n. gen. Willard, p. 258.

2000 Acrosaccus Willard; Holmer \& Popov, 2000, p. 86.

Acrosaccus? rotundus (Nicholson 1873)

(Figure 3a-b,d)

v. 1873 Dawsonia rotunda [sic.] Nicholson, pp. 141-142, Figs 3c-3d'.

Type material. Lectotype NHM P1982.1.

Additional material. Syntypes: NHM P1984.2-3, P1985.3 (13 valves: 2 dorsal, 5 pedicle, 6 indet.)

Type locality. Lévis Shale, Point Lévis, Quebec, Canada. Lévis Formation, Ordovician (Arenig).

Description. Shell unequivalved with subcircular outline, equally biconvex. Beak slightly submarginal on one valve and submarginal to subcentral on the other. Anterior-posterior valve length 2.1-2.9 mm, valve breadth 2.1-3.0 
$\mathrm{mm}$; length-breadth ratio $0.95-1.1$, typically slightly elongate. Growth lines continuous, some more prominent, regular 0.05-0.1 mm spacing, growth lines more clearly defined towards the anterior margin, particularly in valve with submarginal to subcentral beak.

Remarks. Though no articulated specimen is known, the two valves can be inferred as belonging to a single species as their outlines are indistinguishable, suggesting they once did meet. By comparison with the type species, A. schuleri Willard (1928), the valve with the more marginal beak is assumed to be the dorsal valve, and the valve with the more central beak being the pedicle valve.

As Dawsonia Nicholson is an invalid taxon there is no conflict of names. However, Nicholson's collections need to be supplemented with additional material displaying conjoined valves and internal views for the generic assignment to be confirmed. Until then the taxon should remain in open nomenclature.

We have corrected Nicholson's use of the name 'rotunda' to 'rotundus' as the latter is the neuter gender singular of the nominative case.

Superfamily? Acrotheloidea Walcott \& Schuchert in Walcott, 1908

Family? Acrothelidae Walcott \& Schuchert in Walcott, 1908

Subfamily? Conodiscinae Rowell, 1965

Genus Discotreta Ulrich \& Cooper (1936)

non 1858 Dawsonia Hartt in Dawson, p. 655.

p. 1873 Dawsonia Nicholson, p. 139-140 pars.

* 1936 Discotreta n. gen. Ulrich \& Cooper, 1936, p. 619. 
2000 ?Discotreta Ulrich \& Cooper, 1936; Holmer \& Popov, 2000, p. 94-95.

Remarks. There appears to be some doubt as to the affinity of the genus, with Rowell (1965) considering it Incertae Familae and Holmer \& Popov (2000) expressing a degree of uncertainty in its systematic position. These specimens do not preserve sufficient characters to contribute to the debate. There is no doubt, however, in the status of the generic name, as the invalidity of the name Dawsonia Nicholson avoids conflict.

Discotreta cf. levisensis (Walcott, 1908)

(Figure 3f)

p. 1873 Dawsonia tenuistriata Nicholson; p. 141-142 pars, non Figs 3 c-d'.

* 1908 Acrothele levisensis Walcott, 1908, p. 85, pl. 8, fig. 13.

1936 Discotreta levisensis (Walcott, 1908); Ulrich \& Cooper, p. 619.

1938 Discotreta levisensis (Walcott, 1908); Ulrich \& Cooper, pl. 6a.

1965 Discotreta levisensis (Walcott, 1908); Rowell, p. 281, fig 176.

2000 Discotreta levisensis (Walcott, 1908); Holmer \& Popov, Fig. 47, 2a-d.

Type material. Lectotype GSC 8230, paratypes GSC 8230a, b; housed in the Geological Survey of Canada collections.

Material. NHM P1984.1-3, P1985.3-5 (9 valves).

Type locality. Lévis Shale, Ordovician (Arenig); Point Lévis, Quebec, Canada.

Diagnosis. As Ulrich \& Cooper (1936). 
Description. Shell unequivalved with transversely suboval outline, equally biconvex. Apex submarginal to subcentral and posteriorly positioned, seemingly more submarginal in one valve than the other. Anterior-posterior length $1.0-2.6 \mathrm{~mm}$, valve breadths 1.2-3.4 mm, typical breadth around $3 \mathrm{~mm}$; length-breadth ratio 0.65-0.9, typically 0.8 ; maximum breadth at anterior posterior midpoint. Growth lines continuous, more clearly defined away from the apex, regular $0.06-0.11 \mathrm{~mm}$ spacing throughout the valve.

Remarks. The quality of preservation, especially the lack of internal features, precludes precise assignment. The valve with the most submarginal apex is most likely the ventral valve by comparison with the specimens of $D i$. levisensis illustrated in Holmer \& Popov (2000, Fig. 47, 2a-d).

This species was originally accommodated in Nicholson's (1873) concept of “D." tenuistriata which allowed for considerable variation in the position of the apex by comparison with the variably positioned 'nipples' (actually diagenetic pyrite) in “D. " campanulata. However, as Nicholson's description is of an elongate oval fossil, it seems best to remove this form from "D." tenuistriata and compare it with $D i$. levisensis. As it is unknown whether Nicholson's Point Lévis material was collected from the precise locality and horizon of Walcott (1908), this material should not be assigned topotype status.

Phylum, Class, Order \& Family uncertain Genus "Dawsonia” Nicholson 
p. 1873 Dawsonia Nicholson, pp. 139-140, pars.

p. 1889 Dawsonia Nicholson; Miller, p. 184.

non 1904 Caryocaris Salter; Ruedemann pp. 738-742.

non 1969 Caryocaris Salter; Rolfe in Moore, p. 316.

non 1970 Lockeia James; Osgood, pp. 308-312.

p. 1981 Dawsonia Nicholson; Williams, p. 55.

non 1989 “Dawsonia”; Frey, Fig 7.

Type species. "Dawsonia” campanulata Nicholson; secondary diagnosis, Miller (1889).

Diagnosis. Ovato-triangular carbonaceous fossil consisting of a flat, tapering lobate body and a sharply-delineated, narrow triangular mucro. Specimens range in size from 3-12 mm length and 1-4mm width, with the mucro itself being typically less than $0.5 \mathrm{~mm}$ in length, and seemingly isometric growth.

"Dawsonia” campanulata Nicholson

(Figures 1a-c, 6a-c)

non 1837 Prionotus pristis Hisinger, p. 114, pl. 35, fig. 5.

non 1843 Graptolithus (Prionotus) Sedgewickii [sic] Portlock, p. 318, Pl. 19. Fig. 1.

p. 1866 Graptolites sedgwickii (Portlock) Pl. 17, Fig. 3 pars.

v. 1867 Diplograpsus pristis (Hisinger); Nicholson, pp. 111-113, Pl. 7, Figs 21-21b.

v.* 1873 Dawsonia campanulata Nicholson, pp. 142-143, Fig. 3e-f.

p. 1873 Dawsonia acuminata Nicholson, pp. 142-143, pars. 
v. 1877 Dawsonia sp.; Lapworth, p.7, P1. 7, Figs 23a-d.

1981 Dawsonia campanulata Nicholson; Williams p. 55, Pl. 6, Figs 1-15, P1. 7, Fig. 6.

1995 Dawsonia sp.; Williams, p. 196, Pl. 36, Fig. 16.

\section{Type Material. Lectotype NHM 1976.}

Additional Material. Topotypes in Nicholson's collection NHM P1976; material measured in Fig. 5: BGS GSM 105814-9, GSE 10800-1, 3366, PHW 501553, 18E 73,81,90,94-5,99,102-4,112-3,117 and SM A38754; additional material: SM A20905a-c, A20906; BEL K681; NHM 55641.1-2, 55647.

Type locality. Dob's Linn, near Moffat, Scotland. Birkhill Shale Formation, Silurian: Llandovery: Rhuddanian.

Range \& horizons. Rhuddanian to Aeronian (Llandovery, Silurian) of the British Isles. Birkhill Shale Formation (Moffat Shale Group) in Dob’s Linn, Garpol Linn, Plewlands Burn and Duffkinnel Burn, Southern Uplands, Scotland, and in Coalpit Bay, Donaghadee, Northern Ireland; Skelgill Formation (Stockdale Group) in Spengill, nr Sedbergh, Howgill Fells, and Hol Beck, Skelgill, English Lake District.

Description. As genus.

Remarks. "D." campanulata cannot be easily accommodated in any higher taxonomic group. It is clearly unrelated to graptolite scopulae, and bears little similarly to either phyllocarids or algae. Although recent works have tried to accommodate it in these groups (cf. Rolfe 1969 and Williams 1981, respectively), neither assignment is entirely convincing. Meanwhile, Underwood (1993, Fig 4e) illustrated a carbonaceous fossil that looks conspicuously "Dawsonia"-like as a faecal pellet. In the most detailed recent study of "Dawsonia", Williams (1981) argued that 
it represented a spore-carrying alga. He stated that " $D$." campanulata had an open, flared "posterior margin, giving the [hollow] body a 'crocus flower' type of appearance". However, it is an order of magnitude larger than such spore-carrying alga in the modern oceans (Tappan 1980) and there is no evidence to suggest it had significant three-dimensionality in life. The 'nipples' seen associated with " $D$." campanulata superficially suggest a three dimensionality, but, as noted in section 3 , they actually represent compression of the fossil on to diagenetic pyrite in the sediment. This pyrite notably differs in fabric from the pyrite infill of hollow cavities (cf. Allison 1988; Underwood \& Bottrell 1994). Moreover, “D.” campanulata lacks the morphological variation seen when unambiguously hollow tissues such as the Climacograptus wilsoni vesicle are found flattened in these shales (cf. Williams 1994). And, although the distal margin of “D." campanulata's lobate body may be fragmented (e.g. Fig. 1b), and, at times, less-well delineated than the proximal end and mucro (e.g. Fig. 6b), there are many examples showing a well-defined, rounded distal margin (e.g. Figs 1a,c \& 6a,c), suggesting that this represents variability in preservation rather than a crocus-flower-like morphology. With this in mind, "Dawsonia" is best considered to be a flat problematicum rather than a hollow alga.

\section{Acknowledgments}

Adrian Rushton (NHM) is thanked for his enthusiastic guidance through the Victorian literature, for useful insights throughout this work, and for making available valuable specimens. Rod Branson (Leicester) and Toni Milodowski (BGS) assisted with electron microscopy, and Phil Crabb (NHM) photographed all of Nicholson's type 
material for us. Mike Dorling, Rod Long, Matt Lowe and Dan Pemberton (SM), Peter Crowther and Michael Simms (BEL), Adrian Gunning (City of Glasgow Museum), Ed Landing and Linda Hernick (NYSM) and Mike Howe, Louise Neap and Paul Shepherd (BGS) all provided access to comparative material in their care. Finally, we thank Sarah Gabbott (Leicester) for her eagle-eyed spotting of the Sphaenothallus "Dawsonia". PRW publishes with the permission of the Executive Director, BGS. This is Cambridge Earth Sciences contribution number ES.XXXX.

\section{References}

Allison, P.A. 1988. Taphonomy of the Eocene London Clay biota. Palaeontology 31, 1079-1100.

Bates, D.E.. 1987. The density of graptoloid skeletal tissue, and its implication for the volume and density of the soft tissue. Lethaia 20, 149-156.

Bates, D.E., \& Kirk, N. 1991. The ultrastructure, mode of construction and functioning of Ordovician retiolitid graptolites from the Viola Springs limestone, Oklahoma. Modern Geology 15, 131-286.

Bates, D.E., \& Loydell, D.K. 2000. Parasitism on graptolites. Palaeontology 43, $1143-1151$.

Bengtson, P. 1988. Open nomenclature. Palaeontology 31, 223-227.

Benton, M.J. \& Trewin, N.H. 1978. Catalogue of the type and figured material in the Palaeontology Collection, University of Aberdeen, with notes on the H.A. Nicholson collection. Publications of the Department of Geology and Mineralogy, University of Aberdeen $\mathbf{2}$. 
Benton, M.J. 1979. H.A. Nicholson (1844-1899), invertebrate palaeontologist: bibliography and catalogue of his type and figured material. Royal Scottish Museum information series, Geology 7.

Bulman, O.M.B. \& Rickards, R.B. 1966. A revision of Wiman's dendroid and tuboid graptolites. Bulletin of the Geological Institution of the University of Uppsala 43, $1-73$.

Bulman, O.M.B. 1964. Lower Palaeozoic plankton. Quarterly Journal of the Geological Society, London 120, 455-476.

Bulman, O.M.B. 1970. Graptolithina, with sections on Enteropneusta and Pterobranchia. In Teichert, C. (ed.) Treatise on Invertebrate Palaeontology, Part $V$. Boulder, Colorado \& Lawrence, Kansas: Geological Society of America \& University of Kansas Press.

Cameron, C.B. 2005. A phylogeny of the hemichordates based on morphological characters. Canadian Journal of Zoology 83, 196-215.

Carruthers, W. 1867a. Note on the systematic position of the Graptolites and on their supposed ovarian vesicles. Geological Magazine 4, 70-72.

Carruthers, W. 1867b. Graptolites. Geological Magazine 4, 187.

Carruthers, W. 1867c. Graptolites. Geological Magazine 4, 336.

Carruthers, W. 1868a. A revision of the British Graptolites, with descriptions of the new species, and notes on their affinities. Geological Magazine 5, 64-74 \& 125133.

Carruthers, W. 1868b. Classification of Graptolites. Geological Magazine 5, 199-200.

Churkin, M., Jr., 1966. Morphology and stratigraphic range of the phyllocarid crustacean Caryocaris from Alaska and the Great Basin. Palaeontology 9, 371380. 
Clupáč, I. 1970. Phyllocarid crustaceans of the Bohemian Ordovician. Sbornik Geologických věd, řada P 12, 41-75.

Crowther, P.R. 1978. Graptolite fine structure and its bearing on mode of life and zoological affinities. Unpublished $\mathrm{PhD}$ thesis. University of Cambridge.

Crowther, P.R. 1981. The fine structure of graptolite periderm. Special Papers in Palaeontology 26.

Dawson, J.W. 1868. Acadian Geology. London: Macmillan.

Dilly, P.N. \& Ryland, J.S. 1985. An intertidal Rhabdopleura (Hemichordata, Pterobranchia) from Fiji. Journal of Zoology Series A 205, 611-623.

Dilly, P.N. 1973. The larva of Rhabdopleura compacta (Hemichordata). Marine Biology 18, 69-86.

Dilly, P.N. 1993. Cephalodiscus graptolitoides sp. nov. a probable extant graptolite. Journal of Zoology 229, 69-78.

Dunlop, J.A., Anderson, L.I., Kerp, H. \& Hass, H. 2004 for 2003. A harvestman (Arachnida: Opiliones) from the Early Devonian Rhynie cherts, Aberdeenshire, Scotland. Transactions of the Royal Society of Edinburgh: Earth Sciences 94, 341-354.

Elles, G.L. \& Wood, E.M.R. 1901-1918. A monograph of British Graptolites. London: Palaeontographical Society (Monograph).

Elles, G.L. 1940. Graptogonophores. Geological Magazine 77, 283-288.

Frey, R.C. 1989. Palaeoecology of a well-preserved nautiloid assemblage from a Late Ordovician shale unit, western Ohio. Journal of Paleontology 63, 604-620.

Geinitz, H. B. 1852. Die Versteinerungen der Grauwackenformation in Sachsen und der angrenzenden Länden. Abt. 1. Die Graptolithen. Leipzig. 
Gilchrist, J.D.F. 1915. Observations on the Cape Cephaloscus (C. gilchristae Ridewood) and some of its early stages. Annals and Magazine of Natural History, series 8 16, 233-243

Gürich, G. 1928. Über Dawsonia Nicholson, Peltocaris Salter und über die Graptolithen-Studien von E. Manck. Zentrablatt für Mineralogie, Geologie und Paläontologie 29B, 531-537.

Gurley, R.R. 1896. North American graptolites: new species and vertical ranges. Journal of Geology 4, 63-102.

Gutiérrez-Marco, J.C. \& Lenz, A.C. 1998. Graptolite synrhabdosomes: biological or taphonomic entities? Paleobiology 24, 37-48.

Hall, J. 1865. Graptolites of the Quebec Group. Geological Survey of Canada, Canadian Organic Remains 2, 1-151.

Häntzschel, W. 1965. Vestigia invertebratum et problematica. In Westphal, F. (ed.) Fossilum Catalogus (I: Animalia) 108.

Häntzschel, W. 1975. Trace fossils and problematica. In C. Teichert (ed.) Treatise on Invertebrate Paleontology, Part W, Miscellanea. Boulder, Colorado \& Lawrence, Kansas: Geological Society of America \& University of Kansas Press.

Holmer, L.E. \& Popov, L.E. 2000. Lingulata, Actrotretida \& Siphonotretida. In Kaesler, R.L. (ed.) Treatise on Invertebrate Paleontology. Part H, Brachiopoda. Boulder, Colorado \& Lawrence, Kansas: Geological Society of America \& University of Kansas Press, p 32-146.

Horst, C.J. van der. 1939. Hemichordata. In Bronns, H.G. (ed) Klassen und Ordnungen des Tier-Reichs wissenschaftlich dargestellt in Wort und Bild. Leipzig: Akademische Verlagsgesellschaft. 
Hutt, J.A. 1991. What was their sex life like? In Palmer, D. \& Rickards, R.B. (eds) Graptolites: writing in the rocks. Woodbridge: Boydell Press.

James, J.F. 1885. The fucoids of the Cincinnati Group, Part 2. Journal of the Cincinnati Society of Natural History 7, 161-162.

James, J.F. 1892. Manual of the paleontology of the Cincinnati Group, Part 2. Journal of the Cincinnati Society of Natural History 14, 45-72.

James, U.P. 1879. Descriptions of new secies of fossils and remarks on some others from the Lower and Upper Silurian rocks of Ohio. The Paleonotologist 3, 17-24.

Kaufmann, E.G. 1978. Benthic environments and palaeoecology of the Posidonienschiefer (Toarcian). Neues Jahrbuch für Geology und Paläontologie, Abhandlungen 157, 18-36.

Koren', T. \& Rickards, R.B. 1997. Taxonomy and evolution of Llandovery biserial graptoloids from the southern Urals, western Kazakhstan. Special Papers in Palaeontology 54.

Kozłowski, R. 1947. Les affinites des graptolithes. Biological Reviews of the Cambridge Philosophical Society 22, 93-108.

Kozłowski, R. 1948. Les graptolithes et quelques nouveaux groupes d'animaux du tremadoc de la Pologne. Acta Palaeontologia Polonica 3, 1-235.

Kozłowski, R. 1965. Oeufs fossiles des Cephalopodes? Acta Palaeontologica Polonica 10, 3-9.

Lapworth, C. 1876. Fossils of the Moffat Series. In Armstrong, J., Young, J. \& Robertson, D. (eds) Catalogue of Western Scottish Fossils. Glasgow: Blackie \& Son.

Lapworth, C. 1876-77. On the Graptolites of County Down. Proceedings of the Belfast Naturalists' Field Club-Appendix 4, 125-144. 
Lester, S.M. 1988a. Fine structure of the heart vesicle and pericardium in the pterobranch Rhabdopleura (Hemichordata). American Zoologist 22, 938.

Lester, S.M. 1988b. Settlement and metamorphosis of Rhabdopleura normani (Hemichordata: Pterobranchia). Acta Zoologica 69, 111-120.

Linnaeus, C. 1768. Systema Naturae (edition 12) 3. Holmiae.

Maletz, J., Steiner, M. \& Fatka, O. 2005. Middle Cambrian pterobranchs and the question: What is a graptolite? Lethaia 38, 1-14.

Marr, J.E. \& Nicholson, H.A. 1888. The Stockdale Shales. Quarterly Journal of the Geological Society of London 44, 654-732.

Martill, D.M., Wilby, P.R. \& Williams, N. 1992. Elemental mapping: a technique for investigating delicate phosphatized fossil soft tissues. Palaeontology 35, 869-874.

Matthews, S.C. 1973. Notes on open nomenclature and on synonymy lists. Palaeontology 16, 233-237.

Miller, S.A. 1889. North American Geology and Paleontology. Cincinnati, Ohio: Western Methodist Book Concern.

Moore, R.C. \& Sylvester-Bradley, P.C. 1957. Taxonomy and nomenclature of aptychi. In Moore, R. C. (ed.) Treatise on Invertebrate Palaeontology, Part L. Boulder, Colorado \& Lawrence, Kansas: Geological Society of America \& University of Kansas Press, 465-471.

Neal, M.L. \& Hannibal, J.T. 2000. Paleoecologic and taxonomic implications of Sphenothallus and Sphenothallus-like specimens from Ohio and areas adjacent to Ohio. Journal of Paleontology 74, 369-380.

Nicholson, H.A. 1866. On some fossils from the graptolitic shales of Dumfrieshire. Geological Magazine 3, 107-113. 
Nicholson, H.A. 1867a. Graptolites of the Moffat Shales. Geological Magazine 4, $135-136$.

Nicholson, H.A. 1867b. Graptolites. Geological Magazine 4, 238-239.

Nicholson, H.A. 1867c. On a new genus of Graptolites, with notes on reproductive bodies. Geological Magazine 4, 256-263.

Nicholson, H.A. 1868a. On the nature and zoological position of the Graptolitidae. Annals and Magazine of Natural History, decade 4 1, 55-61.

Nicholson, H.A. 1868b. I. - The Graptolites of the Skiddaw Series, etc. II. - On the classification of Graptolites. Geological Magazine 5, 150-152.

Nicholson, H.A. 1872. A Monograph of the British Graptolitidae. Edinburgh \& London: Blackwood \& Sons.

Nicholson, H.A. 1873. On some fossils from the Quebec group of Point Lévis, Quebec. Annals and Magazine of Natural History, decade 4 11, 133-143.

Nimmo, J. 1847. Fossil Graptolithus. Calcutta Journal of Natural History 7, 358-359.

Oldroyd, D.R. 1990. The Highland controversy: Constructing geological knowledge through fieldwork in Nineteenth-Century Britain. Science and its conceptual foundations series. Chicago: Chicago University Press.

Orr, P.J., Kearns, S.L. \& Briggs, D.E.G. 2002. Backscattered electron imaging of fossils exceptionally-preserved as organic compressions. Palaios 17, 110-117.

Osgood, R.G. 1970. Trace fossils of the Cincinnati area. Palaeontolographica Americana 6, 281-444.

Peach, B.N. \& Horne, J. 1899. The Silurian Rocks of Britain. Vol. I: Scotland. Memoirs of the Geological Survey of the United Kingdom. Glasgow: HMSO.

Portlock, J.E. 1843. Report on the geology of the county of Londonderry, and parts of Tyrone and Fermanagh. Dublin, London. 
Racheboeuf, P., Vannier, J. \& Ortega, G. 2000. Ordovician phyllocarids (Arthropoda; Crustacea) from Argentina. Paläontologishes Zeitschrift 74, 317-333.

Rickards, R. B., Hamedi, M. A. \& Wright, A. J. 1994. A new Arenig (Ordovician) graptolite fauna from the Kerman District, east-central Iran. Geological Magazine 131, 35-42.

Rigby S. 1993. Population analysis and orientation studies of graptoloids from the Middle Ordovician Utica Shale, Quebec. Palaeontology 36, 267-282.

Rolfe, W.D.I. 1969. Phyllocarida. In Teichert, C. (ed.) Treatise on Invertebrate Paleontology. Part R, Arthropoda 4. Boulder, Colorado \& Lawrence, Kansas: Geological Society of America \& University of Kansas Press, p 296-330.

Rowell, A.J. 1965. Inarticulata. In Moore, R.C. (ed.) Treatise on Invertebrate Paleontology. Part H, Brachiopoda. Boulder, Colorado \& Lawrence, Kansas: Geological Society of America \& University of Kansas Press, p 260-296.

Ruedemann, R. 1904. Graptolites of New York. Part I. New York State Museum, Memoir 7.

Ruedemann, R. 1908. Graptolites of New York. Part II. New York State Museum, Memoir 11.

Ruedemann, R. 1934. Paleozoic plankton of North America. Geological Society of America, Memoir 2.

Ruedemann, R. 1936. Ordovician graptolites from Quebec and Tennessee. Journal of Paleontology 10, 385-387.

Ruedemann, R. 1947. Graptolites of North America. Geological Society of America, Memoir 19. 
Rushton, A.W.A. \& Williams, M. 1996. The tail-piece of the crustacean Caryocaris wrighti from the Arenig rocks of England and Ireland. Irish Journal of Earth Sciences 15, 107-111.

Rushton, A.W.A. 2001 for 2000 . The use of graptolites in the stratigraphy of the Southern Uplands: Peach's legacy. Transactions of the Royal Society of Edinburgh, Earth Sciences 91, 341-347.

Salter, J.W. 1863. Note on Skiddaw Slate Fossils. Quarterly Journal of the Geological Society, London 19, 135-140.

Siveter, David J., Sutton, M., Briggs, D.E.G. \& Siveter, Derek J. 2003. An ostracode crustacean with soft parts from the Lower Silurian. Science 302, 1747-1751.

Stebbing, A.R.D. 1970. Aspects of the reproduction and life cycle of Rhabdopleura compacta (Hemichordata). Marine Biology 5, 205-211.

Štorch, P. 1994. Graptolite biostratigraphy of the Lower Silurian (Llandovery and Wenlock) of Bohemia. Geological Journal 29, 137-65.

Størmer, L. 1937. Planktonic crustaceans from the Lower Didymograptus shale (3b) of Oslo. Norsk geologisk tidsskrift 16, 267-278.

Tappan, H. 1980. The palaeobiology of plant protists. San Francisco: W. H. Freeman \& Co.

Theokritoff, G. 1964. Taconic stratigraphy in northern Washington County, New York. Bulletin of the Geological Society of America 75, 171-190.

Törnquist, S.L. 1899. Researches into the Monograptidae of the Scanian Rastrites Beds. Acta Universitatis Lundensis, 35, p. 1-25.

Towe, K. M. \& Urbanek, A. 1972. Collagen-like structures in Ordovician graptolite periderm. Nature 237, 443-445. 
Ulrich, E.O. \& Cooper, G.A. 1936. New genera and species of Ozarkian and Canadian Brachiopoda, Journal of Palaeontology 10, 616-631.

Ulrich, E.O. \& Cooper, G.A. 1938. Ozarkian and Canadian Brachiopoda. Geological Society of America, special paper 13.

Ulrich, E.O. \& Ruedemann, R. 1931. Are the graptolites bryozoans? Bulletin of the Geological Society of America 42, 589-604.

Underwood, C.J. \& Bottrell, S.H. 1994. Diagenetic controls on multiphase pyritization of graptolites. Geological Magazine 131, 315-327.

Underwood, C.J. 1993. The position of graptolites in Lower Palaeozoic planktic ecosystems. Lethaia 26, 189-202.

Urbanek, A. \& Jaanusson, V. 1974. Genetic polymorphism as evidence of outbreeding in graptoloids. In Rickards, R.B., Jackson, D.E. \& Hughes, C.P. (eds) Graptolite Studies in honour of O.M.B. Bulman. Special Papers in Palaeontology 13, 15-18.

Vannier, J., Racheboeuf, P., Brussa, E., Williams, M., Rushton, A.W.A., Servais, T. \& Siveter, D.J. 2003. New cosmopolitan arthropod zooplankters in the Ordovician seas. Palaeogeography, Palaeoclimatology, Palaeoecology 195, 173-191.

von Bromell, M. 1727. Lithographiae Suecanae. Acta literae Sueciae Upsaliae 1, 2pp.

Waern, B., Thorslund, P. \& Henningsmoen, G. 1948. Deep boring through Ordovician and Silurian strata at Kinnekulle, Vestergotland. Bulletin of the Geological Institutions of the University of Uppsala, New Series 32, 337-473.

Walcott, C.D. 1908. Cambrian Brachiopoda: descriptions of new genera and species. Smithsonian Miscellaneous Collections 53, 53-165. 
Williams, S.H. \& Clarke, L.C 1999. Structure and secretion of the graptolite prosicula, and its application for biostratigraphical and evolutionary studies. Palaeontology 42, 1003-1015.

Williams, S.H. 1981. Upper Ordovician and lowest Silurian graptolite biostratigraphy in southern Scotland. Unpublished $\mathrm{PhD}$ thesis, University of Glasgow.

Williams, S.H. 1994. Revision and definition of the C. wilsoni graptolite Zone (middle Ordovician) of southern Scotland. Transactions of the Royal Society of Edinburgh: Earth Sciences 85, 143-147.

Williams, S.H. 1996. Graptolites. In Harper, D.A.T. \& Owen, A.W (eds) Fossils of the Upper Ordovician. Palaeontological Association Field Guide to Fossils 7, 174-201.

Zalasiewicz, J. A. 1984. Dichograptid synrhabdosomes from the Arenig of Britain. Palaeontology 27, 425-429. 


\section{Figure captions}

Fig. 1. (a-c) “D. ” campanulata Nicholson 1873 and (d-f) graptolites with appendages, Dobb's Linn, Birkhill Shale Formation. (a) lectotype, NHM P1976; (b) syntype, NHM P1976; (c) exhibiting a prominent "nipple" and juxtaposed to an indet. monograptid, though preserved on a different sedimentary lamina, NHM P1976; (d) Dittograptus? sp. (Elles 1940) with well-preserved scopulae ('graptogonophores'), SM A13731; (e) nemal vane of ?Pribylograptus incommodus (Törnquist 1899) cf. Crowther (1978) overlain by indet. graptolite, see also Fig. 2h, NHM P1981; (f) detail of poorly-preserved scopula ('graptogonophore') of Hallograptus bimucronatus (Nicholson 1869), the scopula originates from the graptolite to the right, the concentric lines represent progressive growth increments constrained by the scopula's better margin, BU 1420. All specimens photographed under reflected light.

Nicholson's specimens (a-c, e). Scale bar $=1 \mathrm{~mm}(\mathrm{a}-\mathrm{c}, \mathrm{e}-\mathrm{f}), 500 \mu \mathrm{m}(\mathrm{d})$.

Fig. 2. Nicholson's illustrations of supposed graptolite ovarian capsules, including (af) his “Dawsonia" type specimens (Nicholson 1873). (a) “D." acuminata, (b) “D." rotunda, (c-d) “D.” tenuistriata, (e-f) “D. ” campanulata; (g-m) in Nicholson (1872); (n-o) Nicholson's handwritten specimen labels, NHM.

Fig. 3. (a-f) Linguliform brachiopods with camera lucida interpretations and (g) graptolite, from the Lévis Shale, Point Lévis, Quebec, Canada. (a-b, d) Acrosaccus? rotunda (Nicholson 1873): (a) pedicle valve, NHM P1985.3, (b) dorsal valve, NHM P1985.3, (d) lectotype, NHM P1982.1; (c, e) Paterula? tenuistriata (Nicholson 1873): (c) lectotype, NHM P1984.3, (e) counterpart NHM P1984.2; (f) Discotreta cf. 
levisensis (Walcott 1908), lectotype NHM P1984.2; (g) Clonograptus sp., NHM P1982. All specimens photographed under reflected light and are from Nicholson's material. All scale bars $=500 \mu \mathrm{m}$.

Fig 4. Caryocaris acuminata (Nicholson 1873), from the Lévis Shale, Point Lévis, Quebec, Canada. (a) Furcal ramus, lectotype NHM P1985.3; (b) furcal ramus, NHM 1977, (c) telson, NHM P1984.3; (d) a reconstruction of the tail-piece and the whole animal (note schematic carapace). All specimens photographed under reflected light. Scale bars $=500 \mu \mathrm{m}$.

Fig. 5. Morphometric analyses. "D." campanulata (open circles) compared with (a) graptolite scopulae (closed squares), and (b) the furcal rami and telsons of Caryocaris acuminata (combined, filled diamonds). (c) Morphometrics of brachiopod outlines and growth lines (combined) showing distinct populations corresponding to $\mathrm{Di}$. cf. levisensis (open triangles), A? rotunda (filled circles) and $P$ ? tenuistriata (open squares). (d) Absolute sizes (mm) of all of the above specimens (brachiopod outlines shown as closed circles, others as before). Morphometric criteria as illustrated: $\mathrm{L}=$ anterior-posterior length; $\mathrm{W}=$ lateral width; $\mathrm{D}=$ distance from blunt margin to centroid; $\mathrm{C}=$ distance from anterior margin to growth centre of brachiopod. " $D$." campanulata specimens are those listed under additional material in Section 6; brachiopod and Caryocaris specimens are Nicholson's specimens from the Lévis Shale Fm., Point Lévis, Quebec, with specimen numbers listed in Section 6. Graptolite scopulae measurements based on those specimens illustrated in Ruedemann (1908), Elles (1940), Bates \& Kirk (1991), Štorch (1994) and Koren’ \& Rickards (1997). 
Fig 6. High contrast BS SEM images illustrating the preservation and morphology of (a-d) “D.” campanulata, (e) graptolite scopula, (f) brachiopod, and (g) Caryocaris. The low brightness of "Dawsonia" and the scopula indicate preservation as organic compressions; the high brightness of the brachiopod and Caryocaris reflect their primary phosphatic compositions; white areas are accessory diagenetic minerals and weathering products. (a) petal-shaped morph, BGS GSM 105817; (b) bell-shaped morph, BGS GSM 105816; (c) partially overlying and imprinting a diageneitc pyrite to produce a well-developed "nipple" (outlined), SM A20905a; d) close-up of a "nipple" showing its concentric structure defined by diagenetic pyrites, SM A 20905a; (e) holdfast and proximal body of scopula (outlined) attached to graptolite illustrated in Fig. 1d, SM A13731; (f) A. rotunda, syntype NHM P1985.2; g) furcal ramus of $C$. acuminata, NHM P1985. Specimens from the Birkhill Shale Fm. of Duffkinnel Burn (a-b), Coalpit Bay (c, d) and Dobb's Linn (e); and, Lévis Shale Fm., Point Lévis (f-g). Scale bar $=1 \mathrm{~mm}(\mathrm{a}-\mathrm{c}, \mathrm{f}-\mathrm{g}), 500 \mu \mathrm{m}(\mathrm{d}-\mathrm{e})$. 
ALEX PAGE*

MARK WILLIAMS

JAN A. ZALASIEWICZ

Department of Geology, University of Leicester, Leicester, LE1 7RH, UK

*Present address: Department of Earth Sciences, University of Cambridge,

Cambridge, CB2 3EQ

e-mail: aap30@esc.cam.ac.uk

e-mail:mri@le.ac.uk

e-mail: jaz1@le.ac.uk

PHILIP R. WILBY

British Geological Survey, Keyworth, Nottingham, NG12 5GG, UK

e-mail: prwi@bgs.ac.uk

\section{CLAIRE MELLISH}

Palaeontology Department, Natural History Museum, London, SW7 5BD, UK e-mail: c.mellish@nhm.ac.uk 

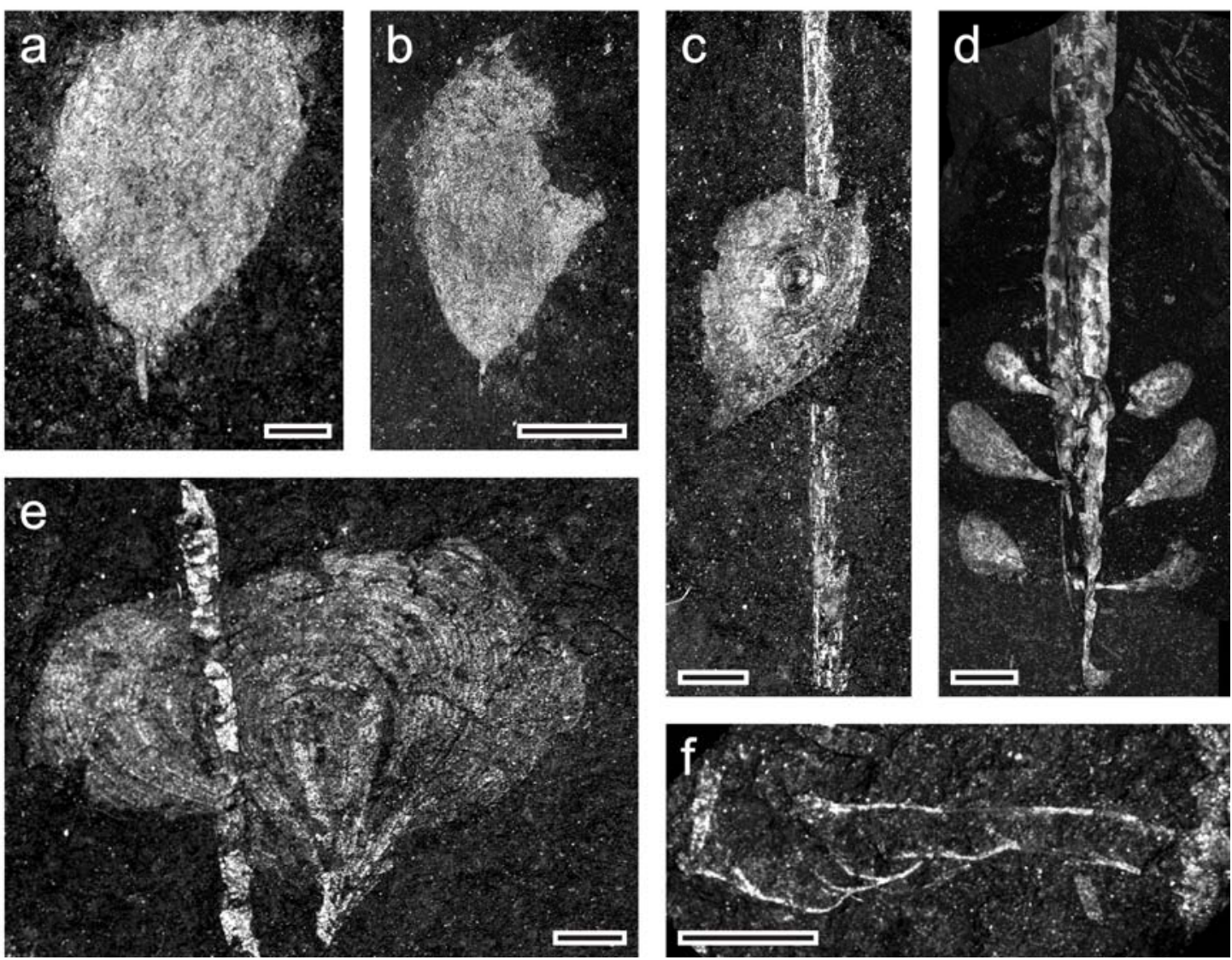

Figure 1. 

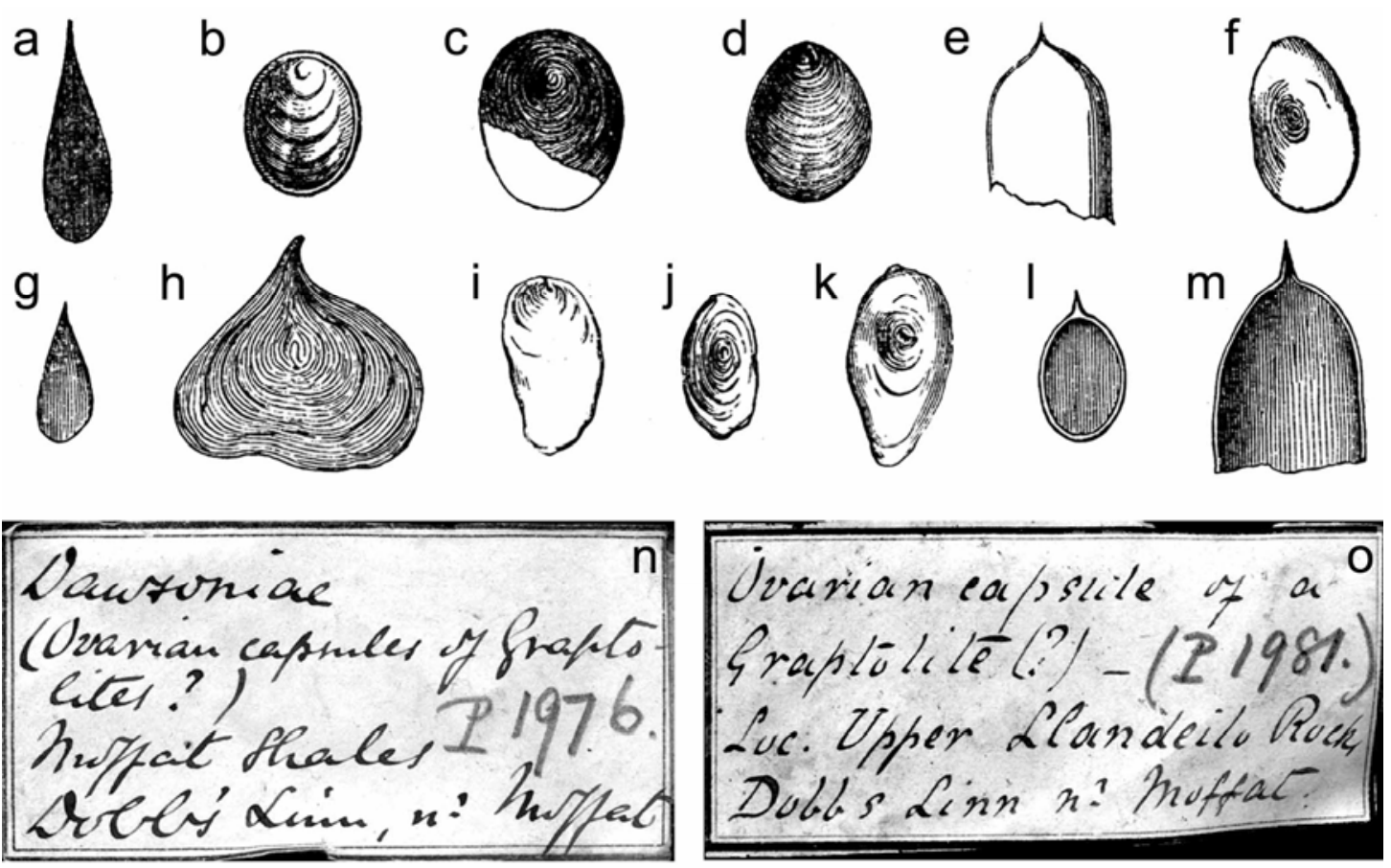

Figure 2. 

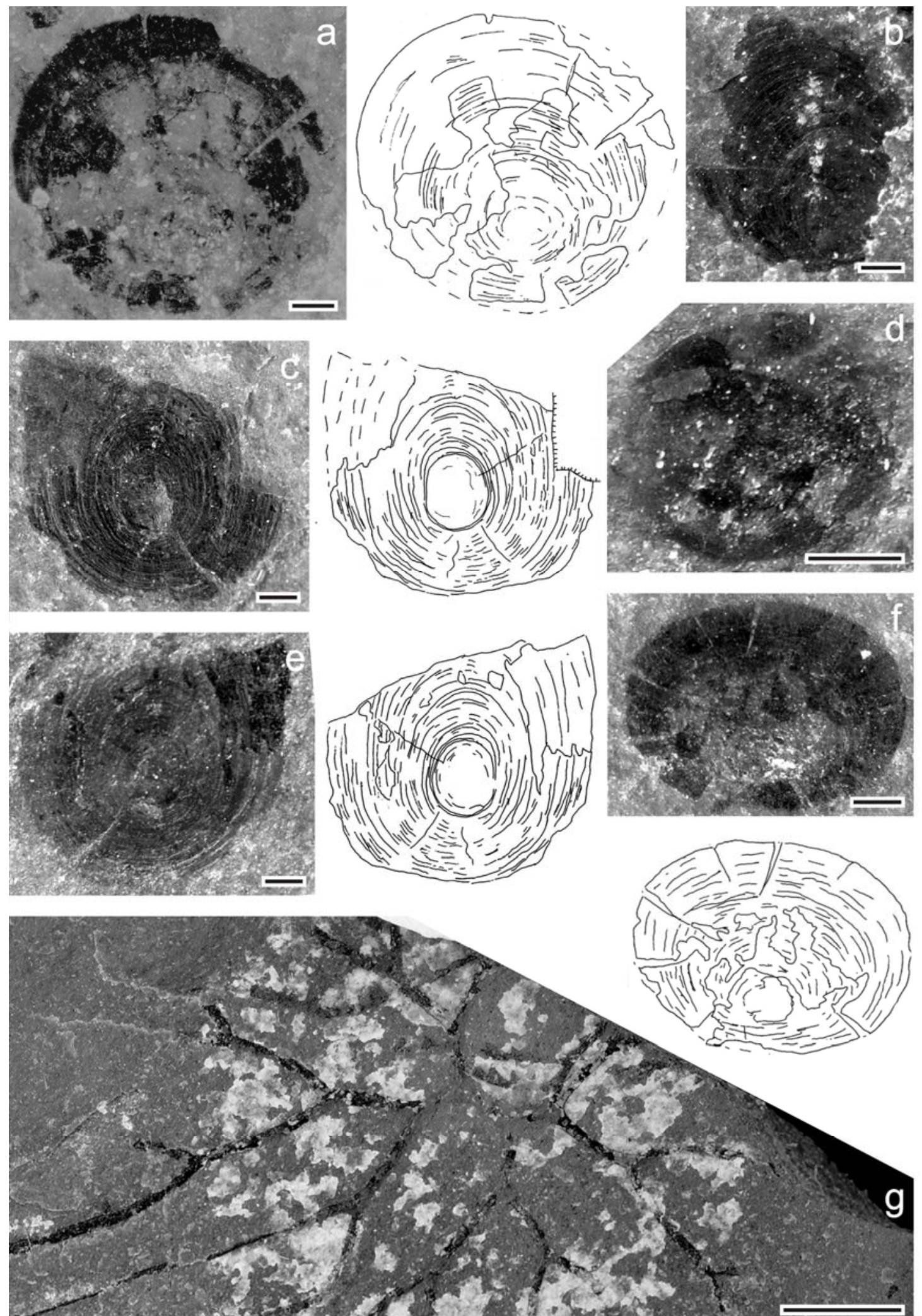

$2,5=5$

Figure 3. 

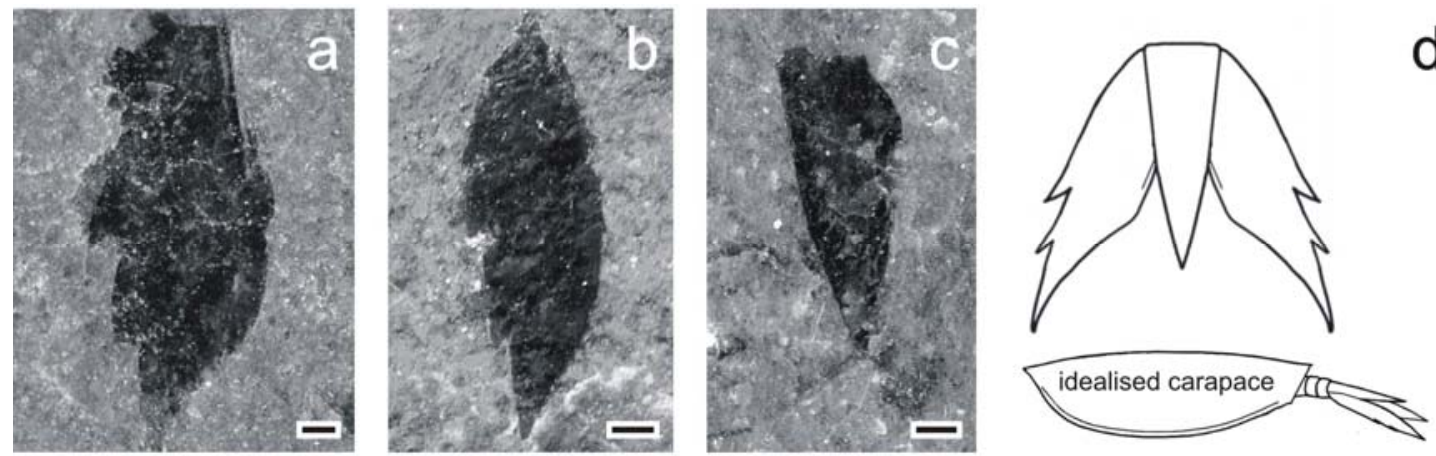

Figure 4. 

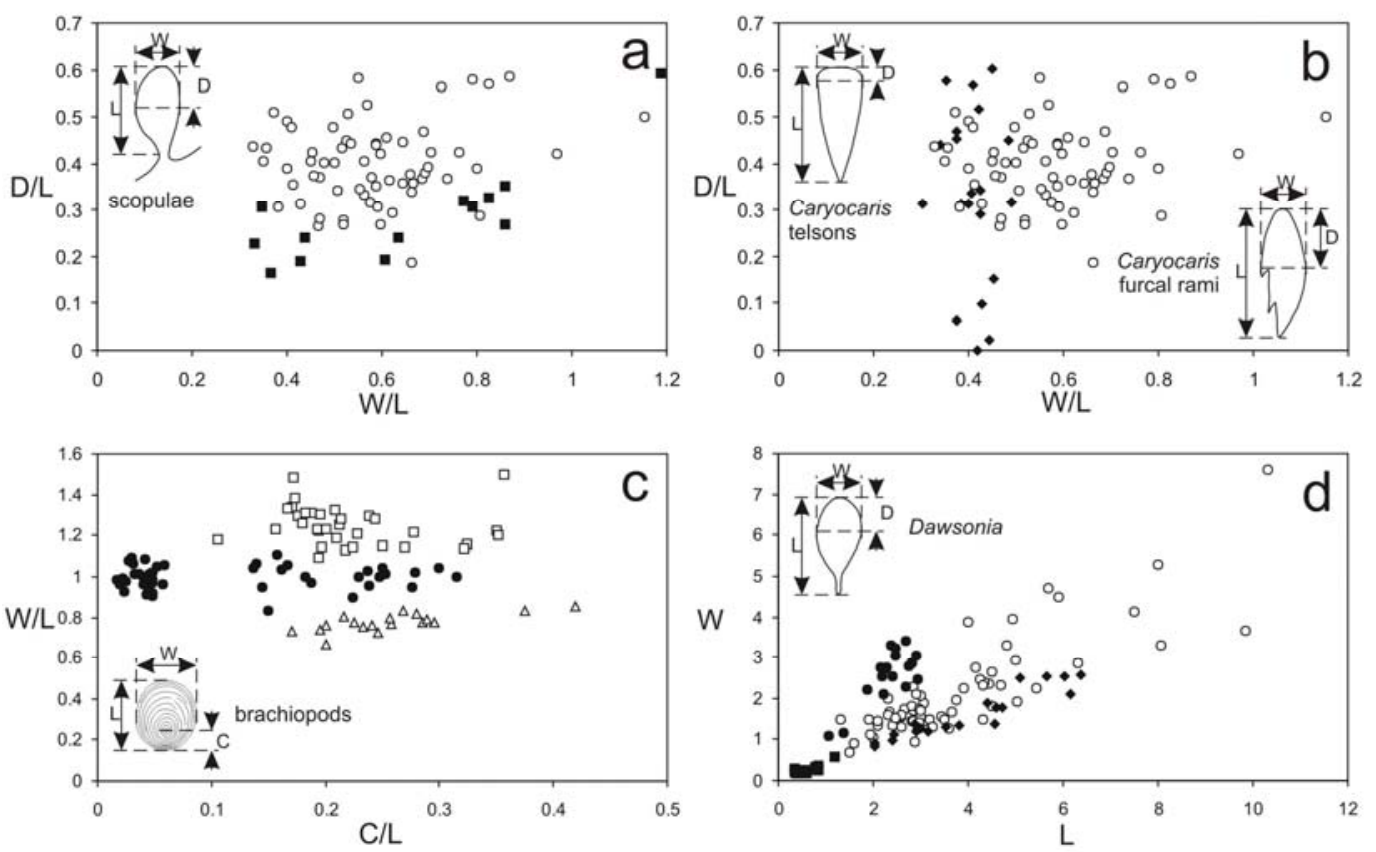

Figure 5. 

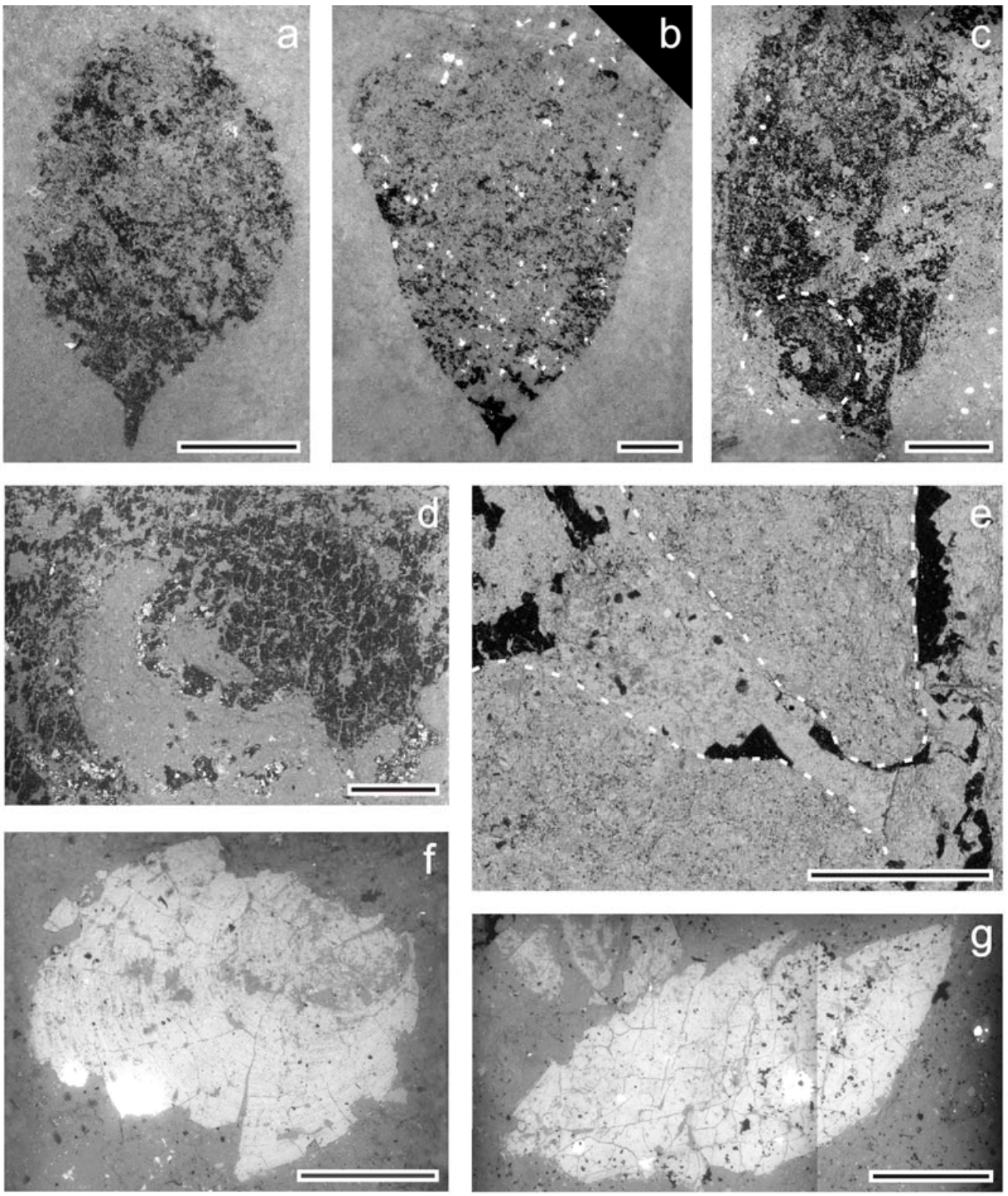

Figure 6. 